Mirosława Radowska-Lisak

\section{Literatura, czyli wspólnota}

DOI: http://dx.doi.org/10.12775/LC.2018.012

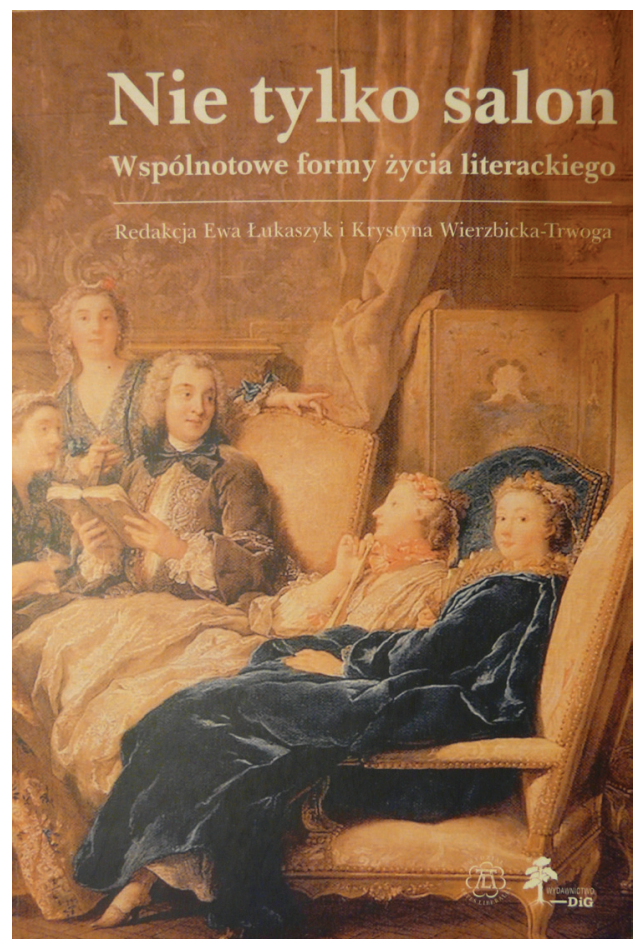
gólnych autorów. Wstępna ocena mniej lub bardziej udanych realizacji takiego zamysłu

* Adiunkt w Zakładzie Literatury Polskiej Romantyzmu i Pozytywizmu Uniwersytetu Mikołaja Kopernika w Toruniu.E-mail: miradlis@umk.pl. dokonuje się już przy pierwszym kontakcie z książką, ograniczającym się zwykle do przegląd spisu treści i pobieżnego zapoznania się z zawartością artykułów. Ale dopiero lektura całego zbioru weryfikuje, na ile trafne były owe pierwotne intuicje i przypuszczenia.

W czytelniku sięgającym po monografię Nie tylko salon. Wspólnotowe formy życia literackiego ${ }^{1}$ pewne obawy o spoistość i stopień wyczerpania problemu budzi zarówno wskazywana w tytułach rozległość poruszanych zagadnień, jak i skromna objętość pracy. Jakkolwiek liczba arkuszy wydawniczych sama w sobie nie stanowi o wartości publikacji, w tym wypadku nie bez przyczyny pojawia się wątpliwość, ile treści można zawrzeć na niewiele ponad stu stronach rozpiętych tematycznie między antykiem a wspólczesnością, pomiędzy Ameryką Łacińską a Europą Środkową, między cywilizacją arabsko-muzułmańską a kulturą zachodnioeuropejską? W recenzowanym zbiorze znalazły się bowiem omówienia tak odległych w czasie i przestrzeni zjawisk, jak rzymskie „późnoantyczne collegia poetarum" (s. 11-21), salon literacki XI-wiecznej Andaluzji (s. 23-32), „florenckie debaty o poezji i estetyce" epoki renesansu (s. 33-42) czy „blogi i portale literackie we Francji” (s. 101-108). Co prawda, nawet znajomość wszystkich tekstów nie pozwala jednoznacznie stwierdzić, czy odpowiedzialnym za przygotowanie tomu, Ewie Łukaszyk i Krystynie WierzbickiejTrwodze, udało się zasadę spójności zachować, nie ma jednak mowy o łatwym do wywołania poczuciu chaosu i „nadmiaru”. Rezultaty badań podjętych na potrzeby tak pomyślanego „studium porównawczego”
1 Łukaszyk, Ewa, Krystyna Wierzbicka-Trwoga (red.) 2016. Nie tylko salon. Wspólnotowe formy życia literackiego. Warszawa: Wydawnictwo DiG. Wszystkie odwołania do recenzowanego tomu podaję poprzez wskazanie w nawiasie numeru strony. 
(s. 8) najcelniej oddałaby prawidłowość zaobserwowana przez Tomasza Wójcika (autora jednego z włączonych do tomu szkiców) w odniesieniu do wymykającego się definicyjnej dyscyplinie pojęcia „kręgu literackiego". Zgodnie z przyjętym sposobem myślenia można by powiedzieć, że to, iż z zebranych studiów przypadku nie wyłania się ścisła teoria wspólnoty literackiej jako zjawiska lub instytucji, nie wyklucza spójnego obrazu konkretnych jej postaci. Pod względem bogactwa form organizowania się wokół literatury recenzowana książka przedstawia się imponująco: od stowarzyszeń erudytów do serwisów społecznościowych dla krytyków-amatorów, od akademickich debat i publicznych odczytów, przez artystyczne salony, bohemy i kawiarnie, na blogach i portalach literackich skończywszy. Mnogość przejawów życia literackiego niesie ze sobą dodatkową wartość poznawczą, ponieważ pomieszczone $\mathrm{w}$ tomie rozprawy oferują znacznie więcej niż zapowiadają ich tytuły. Uwikłane we właściwy opisywanym wspólnotom kontekst geopolityczny i społeczny, wywołują dyskusję na temat rozleglejszych problemów. I tak przypomniana w tekście Ewy Łukaszyk postać Wallady nie tylko komentuje sytuację średniowiecznej poetki Orientu, ale staje się jakby głosem $\mathrm{w}$ „sporze o kobietę muzułmańską i, szerzej, o kształt nowoczesnego islamu”, a zatem także o jakość relacji kulturowych między Wschodem i Zachodem (s. 24). Podobnie dzieje się wówczas, gdy w ślad za Justyną Górny, przyglądającą się wystąpieniom zainspirowanym rozprawą Ottona Weiningera, płynnie przechodzimy od działalności popularyzatorskiej i świadectw „odczytowej recepcji” (s. 61) do refleksji na temat galicyjskiego ruchu emancypacji kobiet, a nawet relatywizacji roli przekładu. Z kolei francuskie „nowe formy rekomendacji i debaty o książkach” (s. 101) sprzyjają namysłowi nad stanem współczesnej krytyki literackiej i jej postępującą deprofesjonalizacją, stawiając ważkie pytania o wartościowanie dzieła i funkcję krytyka w kulturze sieciowej. Tym samym kwestia rozmiarów książki (jak się okazuje - niekiedy zwodniczych) w oczach czytelnika przestaje odgrywać znaczącą rolę jako kryterium jej oceny.

Debatę literaturoznawców, reprezentujących różne ośrodki naukowe w Polsce, otwiera odtworzona w zarysie historia „salonu". Wyeksponowany w tytule i na okładce tomu ${ }^{2}$, uwieczniony słowem i obrazem przez artystów wszech czasów, doczekał się również własnej literatury przedmiotu ${ }^{3}$. Dlatego za słuszną należy uznać decyzję redaktorek, by wyjść poza przestrzeń tej uprzywilejowanej formy „wspólnotowego obcowania z literaturą" (s. 8) i pokazać jej pokrewne, a mniej rozpoznane postaci. Idea towarzyskich spotkań połączonych z wymianą czytelniczych opinii pozostaje jednocześnie punktem dojścia, bo skomentowane $\mathrm{w}$ dwu ostatnich artykułach pamiętniki i serwisy internetowe zwykło się traktować jako wirtualne odpowiedniki tradycyjnych salonów literackich. Co ważne, u zajmujących się nowymi mediami Małgorzaty Marzoch i Anety Bassy powraca obecne również w innych tekstach zjawisko ścierania się kultur oralnej i piśmiennej: w pracy Jerzego Styka, który rekonstruuje przebieg starożytnych uczt $\mathrm{z}$ udziałem poetów, uświetniających wystawne kolacje słownymi grami i zabawami o wyraźnym zabarwieniu agonistycznym; u zafrapowa-

\footnotetext{
$2 \mathrm{Na}$ okładce został wykorzystany obraz JeanaFrançois de Troy Lektura Moliera.

3 Zważmy np. na hasła zawarte w słownikach: Teresa Kostkiewiczowa (red.) 2002. Słownik literatury polskiego oświecenia. Wrocław: Zakład Narodowy im. Ossolińskich Wydawnictwo; Józef Bachórz, Alina Kowalczykowa (red.) 2002. Słownik literatury polskiej XIX wieku. Wrocław: Zakład Narodowy im. Ossolińskich Wydawnictwo; Józef Bachórz et al. (red.) 2016. Słownik polskiej krytyki literackiej 1764-1918. Pojęcia - terminy - zjawiska - przekroje. T. 2. Toruń-Warszawa: IBL PAN, ILP UMK.
} 
nej fenomenem hybrydycznych akademii włoskich Barbary Niebelskiej-Rajcy czy we fragmencie rozważań Tomasza Wójcika, kiedy mowa o odchodzeniu w kołach literackich od dominującej przed XIX wiekiem formy oralnej. Już kilka wskazanych powyżej przykładów potwierdza wysoką rangę zagadnienia $\mathrm{w}$ dziejach kultury i niesłabnącą od lat żywotność problemu na forum akademickim. Poświadczone obserwacjami współtwórców tomu przejawy oralności korespondują z ustaleniami klasyków teorii (takich jak Paul Zumthor) ${ }^{4}$. Innym znów razem przywodzą na myśl tezy stawiane przez współczesnych specjalistów od historii i ontologii czytania, przekonanych tak o kluczowym udziale praktyk oralnych w życiu literackim i w pracy naukowej, jak o społecznym pochodzeniu nawyku lektury ${ }^{5}$. Znosząc wyznaczone przez tzw. szkołę komunikacji z Toronto i jej zwolenników granice między kulturą żywego słowa a światem pisma, opublikowane studia stają się kolejnymi, dodajmy - niezwykle interesującymi egzemplifikacjami „złudzenia Wielkiego Podziału" i jako takie stanowią przyczynek do wielokierunkowych badań prowadzonych w tym zakresie.

Śledzenie ewolucji „zbiorowego wymiaru życia literackiego" (s. 8) staje się możliwe dzięki zastosowanemu w książce

4 Zdaniem Zumthora (2010: 151), grupa społeczna może się wyłonić tylko dzięki oraturze ze względu na integrującą i stabilizującą funkcję głosu poetyckiego.

5 Na dowód czego przywołajmy wypowiedź Jeana Hébrarda, francuskiego historyka książki, badacza "społecznych form rozmowy": „Twórczość [...] nie jest nigdy samotna. Lektura również nie” („Rozmowa III: Jean Hébrard, Między oralnością a piśmiennością"; Rodak 2009: 123, 131). Wtóruje mu niejako Elizabeth Long, według której „nawyk lektury jest z gruntu społeczny. [...] Większość odbiorców potrzebuje wsparcia w postaci rozmów z innymi czytelnikami, udziału w środowisku społecznym, w którym książki w is z a w powietrzu" (Long 2015: 94-95).

6 Takiego określenia użył wspomniany wcześniej Hébrard i przy jego pomocy objaśniał m.in. profil własnej praktyki badawczej. porządkowi chronologicznemu (trudno zresztą wyobrazić sobie, by w tego typu publikacji był w stanie sprawdzić się jakikolwiek inny układ). Jednak przyjęta metoda organizacji materiału obnaża zarazem pewne jej słabości. Przede wszystkim wzmacnia nieuniknione, lecz czasem dosyć dotkliwe wrażenie historycznej nieciągłości ( $w$ tomie pomija się np. okres od późnej nowożytności do połowy XIX wieku, podczas gdy problematyka wspólnot literackich początku ubiegłego stulecia została rozwinięta w kilku osobnych opracowaniach). Ponadto „białe plamy” na osi czasu mogą wpłynąć na rozluźnienie związków logicznych między sąsiadującymi ze sobą szkicami (dość wspomnieć, że „próbę teorii” posługującą się przykładem kręgów skupionych wokół Mallarmégo, Georgego i Czechowicza poprzedza artykuł poświęcony późnorenesansowej, opartej na wspólnocie intelektu, Akademii Alteratów). Trudno natomiast upominać się o tematy nieobecne bądź niedoreprezentowane, gdy poza świadomością ograniczeń natury technicznej weźmie się pod uwagę specyfikę i szeroki zakres badań podejmowanych przez patronujący wydawnictwu Wydział „Artes Liberales” Uniwersytetu Warszawskiego - jednostkę naukowo-dydaktyczną, która stawia sobie za główny cel inicjowanie i koordynowanie przedsięwzięć humanistycznych o charakterze interdyscyplinarnym i międzynarodowym.

To, co konsekwentnie łączy wszystkie artykuły, a równocześnie podnosi merytoryczną wartość tomu, zasadza się na sztuce formułowania pytań i wniosków daleko wykraczających poza zasadniczy przedmiot zainteresowania. Można by wymienić przynajmniej kilka sprzyjających temu okoliczności. Po pierwsze, autorzy studiów chętnie poszukują właściwości ogólnych przy okazji opisywania problemów nowych, rzadziej eksplorowanych, z pewnych względów kło- 
potliwych. Z pewnością należą do nich „zanurzona w Internecie”, prężnie rozwijająca się krytyka literacka „fazy przejściowej” (s. 108) i przywoływany już dwukrotnie krąg literacki, którego teoretyk za pomocą definicji negatywnej próbuje wyłonić konstytutywne cechy „koła”. Na marginesie wypada dodać, że argumentacji tej nie kwestionują częściowo zaprzeczające opisowi wyróżniki Prager Kreis; przeciwnie, osobliwości zauważone przez autorkę szkicu wchodzącego $\mathrm{w}$ dialog $\mathrm{z}$ wywodem poprzednika utwierdzają w przekonaniu o zasadności skonstruowania modelu, wobec którego możliwe będzie tropienie ewentualnych odstępstw. Bez wątpienia wyniki analiz przeprowadzonych na potrzeby publikacji w przyszłości mogą stanowić podstawę do dalszych badań na tym polu, spełniając niejako oczekiwania redakcji wyrażone we Wprowadzeniu, bowiem Ewa Łukaszyk i Krystyna WierzbickaTrwoga zakończyły krótką prezentację zbioru słowami: „Mamy nadzieję, że nasz tom, konfrontujący różne formy wspólnotowego uprawiania literatury, wniesie również wkład do badań życia literackiego w ogólności” (s. 9).

Recz kolejna, o której pojawiły się już wcześniej wzmianki, dotyczy sytuacji porównywania, zestawiania względnie stałych i zmiennych cech zjawisk w zależności od towarzyszącego im kontekstu. Obok wspominanego udziału żywiołu oralnego na przestrzeni epok i przeobrażającej się wraz z procesem instytucjonalizacji i technologizacji - idei i praktyki salonu literackiego warto wymienić kompleks dyspozycji czytelnika, który w cyfrowym otoczeniu, za sprawą nowoczesnych narzędzi komunikowania, stopniowo „z pasywnego odbiorcy dzieła [...] zmienia się w aktywnego nadawcę przekazu” (s. 101).

Zwróćmy następnie uwagę na to, że spostrzeżenia związane $\mathrm{z}$ poszczególnymi przypadkami mogą nieoczekiwanie odsłaniać złożoność i nieoczywistość zjawisk ponadczasowych i ponadnarodowych. Ogląd wybranego fragmentu rzeczywistości każe się wówczas zastanowić nad dostrzeżonymi mechanizmami w skali makro. Udokumentowany przez Styka przykład cesarza Majoriana, sprowadzonej przezeń na dwór w Arles grupy poetów i narastającej popularności przybyłych do Galii artystów wśród mieszkańców miasta burzy potoczny obraz mecenatu jako układu dwustronnego między darczyńcą a beneficjentem. Chociaż zasady udzielania pomocy materialnej (zwykle wraz ze wsparciem symbolicznym) podlegały istotnym zmianom, aktualne pozostaje pytanie o charakter i stopień oddziaływania inicjatywy mecenasa na szerszą publiczność literacką. Bardzo interesujące wydaje się również stwierdzenie Justyny Górny na temat pozornej nietrwałości odczytów, które przecież zyskują „drugie życie” „w relacjach prasowych, stając się przedmiotem medialnych analiz, a tym samym budulcem przestrzeni publicznej” (s. 60). Zdarza się, że włączenie nieuwzględnionego wcześniej kontekstu rzuca inne światło na zagadnienia nienowe. Pod tym kątem warto poświęcić oddzielną uwagę choćby kawiarniom literackim, które powszechnie uchodziły za demokratyczne i egalitarne instytucje życia literackiego. Tymczasem Karolina Krasuska ukazuje wyłaniającą się z narracji berlińskich ekspresjonistów początku XX wieku wizję rażących podziałów według płci, które w granicach ówczesnych „przestrzeni równości” spychały kobiety na niezasłużenie niską pozycję. Konstatacji i sugestii podobnie nieoczywistych wobec utrwalonych w nas sądów i wyobrażeń można znaleźć w książce znacznie więcej, a ich odkrywanie przydaje lekturze atrakcyjności.

Wreszcie, zważmy na nieustanne podkreślanie znaczącej roli czynników pozaliterackich, które mogą wspierać bądź ogra- 
niczać twórczość artystyczną na wszystkich etapach jej „uprawiania” i „konsumowania”. Ewa Kobyłecka-Piwońska przekonuje, że z takich zależności zdają sobie sprawę zarówno interpretatorzy, jak i pisarze, a wśród nich - Witold Gombrowicz. Przygotowując swe ustne wypowiedzi w okresie argentyńskiej emigracji, autor Trans-Atlantyku musiał się liczyć choćby z wpływem wyboru języka i miejsca prelekcji na skład audytorium.

W tym momencie należy odnotować narzucającą się natychmiast prawidłowość, że język, jakim posługują się współtwórcy monografii, kojarzy się raczej z nomenklaturą socjologiczną aniżeli historyczno- czy teoretycznoliteracką. Nie powinno to jednak zaskakiwać, skoro problematyka tomu obejmuje węzłowe zagadnienia socjologii autora, socjologii dzieła czy socjologii życia literackiego. Zbieżność tę odzwierciedlają zwłaszcza dociekania Małgorzaty Marzoch na temat autoprezentacji pisarza, odświeżając w pamięci koncepcje "autora-marki” i „multimedialnego projektu” zilustrowane przykładem zabiegających o kształtowanie własnego wizerunku Jacka Dehnela i Michała Witkowskiego (Antonik 2014). Socjologicznym z gruntu słowem-kluczem staje się zresztą sama „wspólnotowość” wskazująca na istnienie szczególnego rodzaju intymnych więzi łączących członków literackiej zbiorowości. Socjologicznoliteracką perspektywę akcentuje także zaznaczona nieco wcześniej, a właściwa nauce o społeczeństwie funkcja demaskatorska. Co więcej, bliska stanowisku socjologów literatury pozostaje sylwetka pisarza ( $\mathrm{w}$ pierwszym rzędzie - istoty społecznej) i sposób rozumienia dzieła literackiego, postrzeganego $\mathrm{w}$ kategoriach procesu, zjawiska społecznego i formy komunikacji, nie zaś jako skończonego, autonomicznego, zastygłego w czasie „zbioru zapisanych słów” (s. 55). Takie dynamiczne ujęcie skupia się na po- zaartystycznych warunkach powstawania i funkcjonowania literatury, która rodzi się i podtrzymuje swój byt we wspólnocie. Bez uczonych debat i salonowych konwersacji stałaby się po prostu martwa.

Tematyczna różnorodność, udane łączenie zabiegów analitycznych z syntezą oraz dialogiczna struktura tekstów składających się na Wspólnotowe formy życia literackiego czynią prezentowany zbiór cennym źródłem wiedzy dla przedstawicieli wielu dziedzin humanistyki, zwłaszcza zaś dla tej grupy badaczy, którzy lokują swe zainteresowania na pograniczu nauk. Niewykluczone, że poznawcze walory tomu docenią również zaangażowani w organizację życia literackiego czytelnicy spoza uniwersytetu. Ciekawe, co do tego, inspirującego skądinąd, filologicznego wielogłosu wniósłby odpowiednio wkomponowany komentarz socjologa.

\section{Bibliografia}

Antonik, Dominik 2014. Autor jako marka. Literatura $w$ kulturze audiowizualnej społeczeństwa informacyjnego. Kraków: Towarzystwo Autorów i Wydawców Prac Naukowych „Universitas”.

Long, Elizabeth 2015. „O społecznej naturze czytania”. Tłum. Maciej Maryl. W: Grzegorz Jankowicz, Michał Tabaczyński. Socjologia literatury. Antologia. Kraków: Korporacja Ha!art.

Łukaszyk, Ewa, Krystyna Wierzbicka-Trwoga (red.) 2016. Nie tylko salon. Wspólnotowe formy życia literackiego. Warszawa: Wydawnictwo DiG.

Rodak, Paweł 2009. Pismo, ksiązka, lektura. Rozmowy: Le Goff, Chartier, Hébrard, Fabre, Lejeune. Warszawa: Wydawnictwa Uniwersytetu Warszawskiego.

Zumthor, Paul 2010. „Pamięć i wspólnota”. Tłum. Maciej Abramowicz. W: Literatura ustna. Wyb. Przemysław Czapliński. Gdańsk: słowo/obraz/terytoria. 